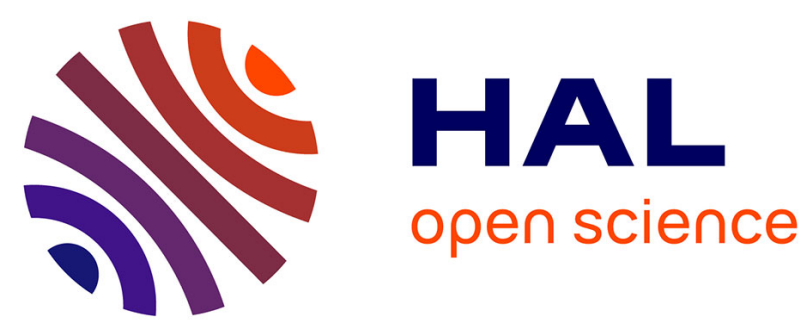

\title{
Recovery of valuable components and inactivating microorganisms in the agro-food industry with ultrasound-assisted supercritical fluid technology
}

\author{
Mohamed Koubaa, Houcine Mhemdi, Jacques Fages
}

\section{- To cite this version:}

Mohamed Koubaa, Houcine Mhemdi, Jacques Fages. Recovery of valuable components and inactivating microorganisms in the agro-food industry with ultrasound-assisted supercritical fluid technology: Review. Journal of Supercritical Fluids, 2018, 134, p.71-79. 10.1016/j.supflu.2017.12.012 . hal01667072

\section{HAL Id: hal-01667072 \\ https://hal.science/hal-01667072}

Submitted on 1 Feb 2018

HAL is a multi-disciplinary open access archive for the deposit and dissemination of scientific research documents, whether they are published or not. The documents may come from teaching and research institutions in France or abroad, or from public or private research centers.
L'archive ouverte pluridisciplinaire HAL, est destinée au dépôt et à la diffusion de documents scientifiques de niveau recherche, publiés ou non, émanant des établissements d'enseignement et de recherche français ou étrangers, des laboratoires publics ou privés. 


\title{
Recovery of valuable components and inactivating microorganisms in the agro-food industry with ultrasound-assisted supercritical fluid technology
}

\author{
Mohamed Koubaa ${ }^{\mathrm{a}}$, Houcine Mhemdi ${ }^{\mathrm{a}}$, Jacques Fages ${ }^{\mathrm{b}, *}$ \\ a Sorbonne Universités, Université de Technologie de Compiègne, Laboratoire Transformations Intégrées de la Matière Renouvelable (UTC/ESCOM, EA 4297 TIMR), Centre \\ de Recherche de Royallieu, CS 60319, 60203 Compiègne, France \\ ${ }^{\mathrm{b}}$ Université de Toulouse, Ecole des Mines d'Albi, CNRS, Centre RAPSODEE, 81013, Albi, France
}

\section{G R A P H I C A L A B S T R A C T}

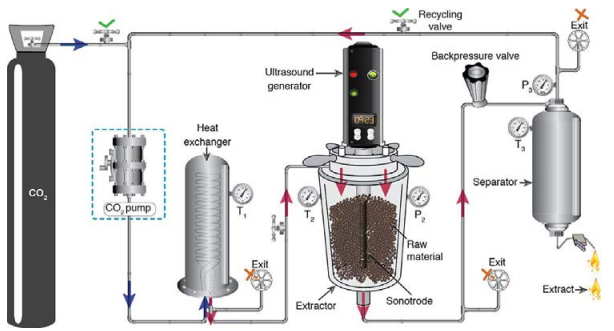

\begin{abstract}
A B S T R A C T
Food industry is increasingly interested in replacing conventional processes of plant extraction, as well as microbial inactivation, by alternative, greener and cheaper techniques. In many cases, chemical extraction processes are hindered by several drawbacks such as the use of chemical solvents, which is associated with many health and environmental issues. Furthermore, the use of high temperatures to improve and/or accelerate the processes, which may affect and degrade the thermolabile compounds, is usually required. Among the most promising techniques that could be competitive to the current extraction methods of molecules from plant matrices and microbial inactivation of food products, ultrasound assisted supercritical fluid extraction has taken great interest. This non-exhaustive review, covering the last 20 years, gives a critical commentary on the main published results using this emerging technology. Promising prospects opened up by new applications are described, without omitting the main limitations still to be overcome for a harmonious industrial development of these technologies.
\end{abstract}

\section{Introduction}

Traditionally, the recovery of valuable components (e.g., poly phenols, sterols, colorants, seed oils, etc.) from plant matrices is mainly based on pressing and/or liquid solid extraction (e.g., maceration, percolation, decoction, infusion, etc.), which consists of using hot water and/or organic solvents such as hexane, ethanol, etc. However, al though reaching high extraction yields in some cases, undesirable consequences such as quality deterioration and degradation of valuable compounds may occur [1,2]. For instance, oil extraction from canola seeds is industrially based on several pre processing steps followed by pressing, expelling most of the oil but also giving meal with $\approx 20 \% \mathrm{wt}$ oil, which is then extracted meaning percolation with hexane. The re covered oil is then refined via a sequential process including i) de gumming, ii) acidification and neutralisation, iii) washing, iv) bleaching, v) winterization, and vi) deodorisation. Besides the use of 
toxic solvent (hexane) that is associated with health, environment, and economic issues, 1) the whole process requires high energy consump tion (approximately 40 and $10 \mathrm{kWh} /$ ton of canola seed processed, for oil extraction and oil refining, respectively) [3], and 2) oil recovered by hexane is of poor quality due to the degradation of thermolabile com pounds, and the low solubility of high added value compounds (i.e. polyphenols) in hexane. This example and others have incited both researchers and food industries to investigate and evaluate novel ex traction or valorization processes that meet the requirements of a green process concept. This concept aims to avoid/minimize the use of or ganic solvents, along with other benefits such as shortening the treat ment time, decreasing the processing temperature, intensifying the mass transfer process, increasing the extraction yields, preserving high extract quality, and reducing the energy consumption [4,5]. These novel extraction processes have been classified as emerging, alter natives, innovative, or non conventional technologies and are including a wide range of techniques (e.g., ultrasound assisted extraction, su percritical fluid extraction, microwave assisted extraction, high pres sure processing, pulsed electric fields, high voltage electrical dis charges, gas assisted mechanical expression, etc.) [6 8]. Besides the features cited above dealing with the green extraction concept, some of the non conventional technologies allow pasteurising or sterilising the extraction medium and provide safer products by inactivating the mi crobial burden. For instance, it was widely known that high pressure processing [8 10], pulsed electric fields [11 13], ultrasounds [14], supercritical fluids [15], and other technologies are able to inactivate contaminating microorganisms including in some cases viruses [16,17]. This ability allows further reducing the heating steps (e.g., for ster ilization, pasteurization), which minimizes the energy consumption and preserves the most thermolabile substances from degradation. Com bining simultaneously a conventional process with a non conventional one for further efficiency has been investigated through different re search works. For instance, gas assisted mechanical expression (GAME) involving the combination of mechanical expression and supercritical fluid extraction has been investigated, and demonstrated interesting results compared to individually applied processes [18 20]. Other works have been focused on combining simultaneously two non con ventional extraction processes, such as the use of ultrasound technology assisted by supercritical carbon dioxide $\left(\mathrm{sc}^{\mathrm{CO}} \mathrm{CO}_{2}\right)$ as solvent. This tech nique called ultrasound or ultrasonic assisted supercritical fluid ex traction (US SFE) was successfully applied to extract seed oils, anti oxidants and high added value compounds, as well as to inactivate microorganisms. In fact, the use of $\mathrm{sc}^{\mathrm{CO}_{2}}$ as solvent instead of other organic solvents (e.g., hexane) contributes to limit and minimize the pollution hazards, although in the case of polar molecules extraction, adding co solvents to $\mathrm{CO}_{2}$ (i.e., ethanol) could be required. Ultrasounds, on the other hand, allow the extraction of both polar and non polar molecules. Therefore, combining these two technologies is a key point to further enhance the mass transfer of targeted compounds from solid matrix to sc $\mathrm{CO}_{2}$ [21]. This review is thus devoted to discuss for the first time 1) the current insights into the use of US SFE as emerging tech nology for the recovery of intracellular components from plant ma trices, and its potential to efficiently inactivate microorganisms, in this latter case the process will be noted US SFI and 2) the limits to be overcome towards the industrialization of this technology.

\section{Current state of ultrasound assisted supercritical fluid extraction (US-SFE)}

Ultrasound assisted extraction (UAE) is an advantageous alternative to conventional extraction techniques (liquid/liquid extraction (LLE), solid phase extraction (SPE), and Soxhlet). When a large negative pressure is applied to a liquid, sonochemical phenomenon associated with acoustic cavitation and the formation of micro bubbles occurs (Fig. 1), constituting thus the base of UAE [22]. When growing to un stable size, the created bubbles collapse violently, which is associated with the release of an intense local energy with important chemical (i.e., free radicals) and mechanical effects (i.e., micro jets) [23]. When bubble collapse phenomenon occurs, increased temperatures and pressures to several thousand degrees and more than 1000 atmo spheres, respectively, are generated. Many parameters are affecting the extraction efficiency, including the effects of solution, power, fre quency, sonication time, and the type of treated material. These para meters were recently reviewed [24].

UAE is a promising technique, with various benefits, that was widely applied to extract valuable compounds from plant matrices [25]. UAE is harmless for operators, safe to use, and with low maintenance costs. Therefore, it has been acquired by several industries to replace the conventional extraction techniques (i.e., LLE $\cdots$ ), as it could be op erated rapidly in a broad range of solvents for large scale preparations suited for industrial purposes [26,27]. For instance, industrial scale up extraction of polyphenols from apple pomace was reported in the lit erature, demonstrating relevance and more sustainable technology to current conventional methods [28,29].

UAE is usually using liquid solvents (e.g., water, ethanol, methanol, DMSO, etc.) [30 33]. However, during the last decade, the use of su percritical fluids as solvent for UAE experiments has drawn more at tention [21,34 36]. The use of supercritical fluids instead of liquid solvents allows obtaining pure extract without subsequent removal of the extracting solvent, and often enhances the extraction yield due to the supplementary effect of pressure on the solute solubility. The most widely supercritical fluid used is carbon dioxide $\left(\mathrm{sc} \mathrm{CO}_{2}\right)$. This fluid takes its advantages from the relatively low critical point of $\mathrm{CO}_{2}$ (cri tical temperature $304.2 \mathrm{~K}$; critical pressure $7.38 \mathrm{MPa}$ ), making it sui table to extract thermo sensitive compounds [37]. Furthermore, the non flammability, non toxicity, low cost, and availability at good purity, make it preferred supercritical fluid for industrial applications. Generally, sc $\mathrm{CO}_{2}$ is used to extract hydrophobic or slightly hydrophilic compounds. However, co solvents or modifiers (e.g., ethanol, me thanol, ethyl acetate, etc.) could be added when the extraction of more hydrophilic compounds is targeted. Many industrial applications for the extraction of valuable compounds using sc $\mathrm{CO}_{2}$ currently exist [38] Among them the extraction of nicotine from tobacco as well as caffeine from coffee grains and tea leaves are the most commonly known [39].

The use of pressurized water (either sub or supercritical) has also been reported for the extraction of several molecules from plants (e.g., phenolic and antioxidant compounds $[38,40])$. It can also be used to produce biofuels from agri food residues or non food plants [41,42].

\subsection{Extraction of oils and fats using US SFE}

Mechanical expression and/or hexane extraction is nowadays the most commonly used process to extract oil from oilseeds (soybean, canola, sunflower, cotton, linseed, etc.). At industrial or semi industrial scales, these processes could be combined (i.e., continuous mechanical pressing (expelling) with continuous solvent extraction, and batch hy draulic pressing followed by solvent extraction) [43,44]. After total defatting, the resulting meal is generally used for animal feed or aquaculture production [45]. The need to minimize the use of toxic hexane for oil extraction has led both food scientists and food industry to develop and evaluate novel "clean" extraction processes using al ternative solvents with the numerous advantages cited above. As al ternative to conventional processes based on mechanical expression and/or hexane extraction of vegetable oils, US SFE was evaluated. Fig. 2 shows a schematic illustration of US SFE equipment used at la boratory scale for the extraction of intracellular compounds.

Many works have been cited in the literature to discuss the feasi bility of using US SFE for vegetable oil extraction, and some of them are summarized in Table 1.

As shown in Table 1, different vegetable materials were used for investigation such as particle almonds [35], passion fruit (Passiflora edulis sp.) seeds [47], etc. The effects of operating conditions 


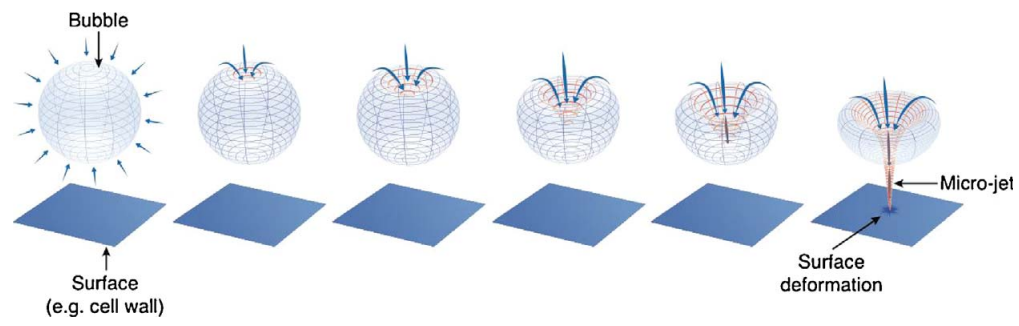

Fig. 1. Creation of a micro-jet through collapsing acoustic cavitation bubbles.

(temperature, pressure, time, $\mathrm{CO}_{2}$ flow rate, frequency and US power) on extraction efficiency and oil quality were studied. The optimal conditions were determined and the results were compared to those obtained with conventional extraction methods. Among others, these works have shown the efficiency of US SFE process to replace con ventional processes.

Therefore, scaling up becomes a major concern and a research work investigated this opportunity by implementing a high power ultrasonic coupled with sc $\mathrm{CO}_{2}$ extraction [48]. The authors developed and vali dated an innovative, robust, stable, reliable and efficient ultrasonic system at pilot scale to assist sc $\mathrm{CO}_{2}$ extraction of oils from different matrices (Fig. 3).

It was shown that ultrasonic energy used in the extraction process represents an efficient way to produce deep agitation in the medium, which enhances the mass transfer processes, due to the presence of some mechanisms (e.g., radiation pressure, streaming, agitation, high amplitude vibrations, etc.). Equipment was designed to fulfill the in dustrial requirements and was successfully validated for SFE of oil from different vegetable matrices. However, further reading in ultrasonic reactor design could be found in the review published by Luo et al. [49]. It was reported that many parameters must be considered in the design of ultrasonic reactors such as reactor type (e.g., bath, probe, flat plate or tube), reactor geometry, transducer design and arrangement, and volume or scale of feedstocks for practical systems. The authors presented and compared different sonochemical reactors (Liquid whistle, Ultrasonic bath, Probe reactor, Cup horn reactor, Resonating tubular reactor (Sonitube), Reverberative flow reactor and Polygonal Reactor) that are commonly used in ultrasound assisted biomass reac tions. The advantages, disadvantages, applications and the possibilities of scale up were presented and discussed.

\subsection{Extraction of high added value compounds using US SFE}

The process of US SFE was not only applied to extract oil from plant matrices but also tested and evaluated to extract high added value compounds as summarized in Table 2.

US SFE process has been used for the extraction of many molecules from different vegetable matrices: gingerols from ginger, lutein from marigold, caffeine from green tea, triterpenic acids (oleanolic and ur solic acids) from Scutellaria barbata, Hedyotis diffusa and Hedyotis cor ymbosa, antioxidant compounds from blackberry (Rubus sp.) and ba gasse (industrial by product), capsaicinoids from malagueta pepper (Capsicum frutescens L., etc.). These studies were performed mainly at the laboratory scale using batch equipment. Most of these studies showed increased extraction rate and yield with US assistance. The authors ascribed this behaviour to the impact of US in disrupting the cell structures, which increases the accessibility of the solvent to the intracellular compartments, and enhances the intra particle diffusivity. It was shown that the optimal operating conditions depend on the target molecule and the properties of the used vegetable material (particle size, moisture content, etc.). Scanning Electron Microscopy images showed that the plant matrix was highly disturbed by the pre sence of ultrasound, which could be the origin of enhanced release of extractable materials. The effects of ultrasound on SFE were more pronounced from larger particles.

\section{Current state of inactivation of microorganisms using ultrasound-assisted supercritical fluid (US-SFI) technology}

In addition to the extraction of valuable substances from plant matrices, the inactivation of microorganisms is another important do main of application of coupling ultrasound and supercritical fluids. There are numerous reports demonstrating that pressurized gases are effective against living microorganisms as is acoustic cavitation gen erated by ultrasound.

Food products are inherently perishable; bacteria, molds and yeasts being responsible for most of the food spoilage. Foodborne diseases cause the illness of several millions of people around the world. In

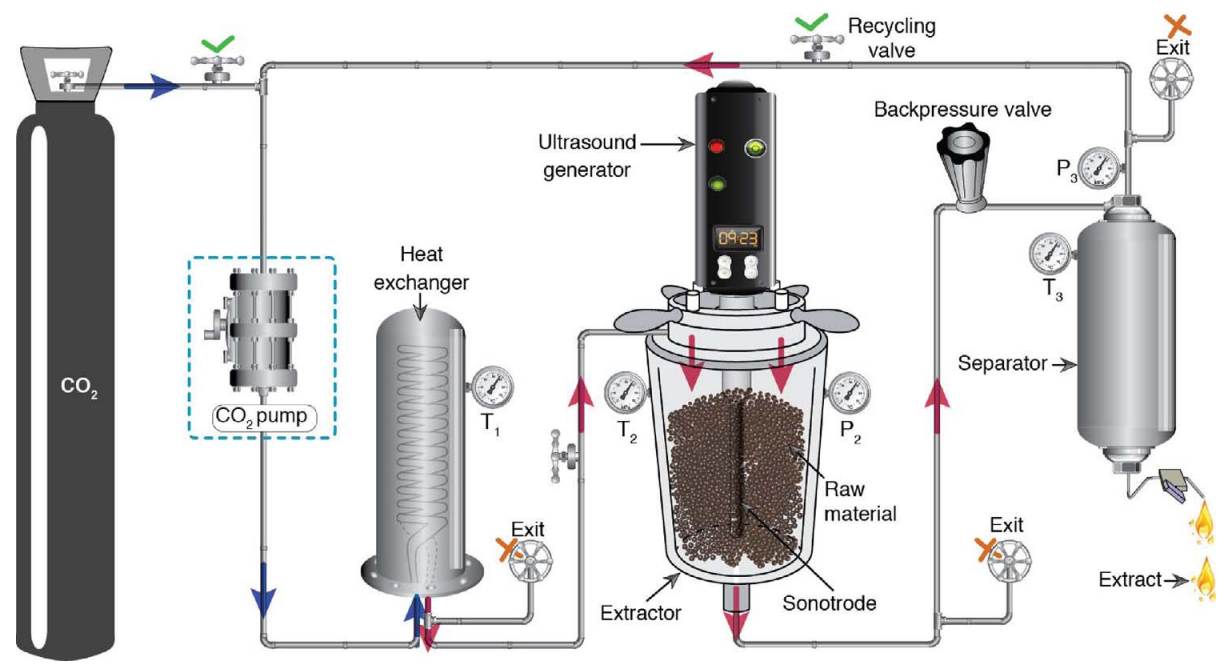

Fig. 2. Schematic representation of US-SFE experimental set-up used at laboratory scale for the extraction of oil from seeds. T, P: temperature and pressure sensors, respectively. 
Table 1

Application of ultrasound-assisted supercritical fluid technology for the recovery of vegetable oil.

\begin{tabular}{|c|c|c|c|}
\hline Description of the study & Process conditions & Major findings & References \\
\hline Extraction of oil from particulate almonds & $\begin{array}{l}\text { Pressure of } 28 \mathrm{MPa} \text {; flow rate of } 20 \mathrm{~kg} / \mathrm{h} \text {, temperature of } \\
55^{\circ} \mathrm{C} \text {, and US power of } 50 \mathrm{~W}(\approx 20 \mathrm{kHz})\end{array}$ & $\begin{array}{l}\text { Enhancement of the extraction kinetics and yields } \\
\text { with an average extraction time of } 8.5 \mathrm{~h}\end{array}$ & [35] \\
\hline $\begin{array}{l}\text { Oil extraction from cumbaru almonds (Dipteryx } \\
\text { alata Vogel) }\end{array}$ & $\begin{array}{l}\text { Optimal conditions of temperature at } 50^{\circ} \mathrm{C} \text {, and } \\
\text { pressure at } 35 \mathrm{MPa} \text {, }\end{array}$ & $\begin{array}{l}\text { Higher initial rate of extraction but no effect in the } \\
\text { final global oil extraction yield }\end{array}$ & [46] \\
\hline $\begin{array}{l}\text { Oil extraction oil from passion fruit (Passiflora } \\
\text { edulis sp.) seeds }\end{array}$ & $\begin{array}{l}\text { Temperature at } 40^{\circ} \mathrm{C} \text { and pressure at } 16 \mathrm{MPa} \text {. US power } \\
\text { at } 160 \mathrm{~W}\end{array}$ & Increase of the oil extraction yield by $29 \%$. & [47] \\
\hline
\end{tabular}

industrialized countries, up to $30 \%$ of the population suffers each year from foodborne diseases [55]. Some foodborne diseases, although well studied and identified, are considered as emergent because of their common occurrence. Among them, Campylobacter spp., Salmonella spp., Listeria spp., and Escherichia coli have been identified as the major causes for foodborne illness [56 58].

The main traditional inactivation processes in food industries in clude heat pasteurization and sterilization. These methods are very effective, if correctly designed and applied, in inactivating pathogenic microorganisms and ensuring shelf stable products. However, due to the use of high temperatures, the most thermo sensitive compounds present in the treated food could be affected and lead to undesirable textural and sensory changes in the final product. In order to avoid these issues and to reduce the high energy consumed during the con ventional processes (pasteurization and sterilization), numerous non conventional technologies (e.g., high pressure processing, pulsed elec tric fields, etc.) have been evaluated and developed.

It has been demonstrated that pressurized gases $\left(\mathrm{CO}_{2}, \mathrm{~N}_{2} \mathrm{O}\right.$, pro pane, etc.) have a bactericidal effect. In his review, Perrut [16] points out that the use of $\mathrm{CO}_{2}$ at the relatively low pressure of $0.6 \mathrm{MPa}$ could divide the time of heat pasteurization by two. This effect is different form the simple hydrostatic pressure effect since it can be obtained at much lower pressures. It involves specific interactions between the microbial cells - and especially the cytoplasmic membrane - and the gas molecules. Both gas dissolution inside the cell and specific decay of the double layer of phospholipidic membranes have been cited as possible mechanisms. Spilimbergo and co workers have published a series of papers demonstrating the possible effect of $\mathrm{sc} \mathrm{CO}_{2}$ on the survival of bacterial populations [59 61].

To enhance the effect of carbon dioxide, several techniques have been proposed such as

1) the application of successive cycles of pressurization/ depressurization to promote cell lysis, 2) the addition of strong oxidants such as hydrogen peroxide or peracetic acid, and 3) the use of pulsed electric fields combined with $\mathrm{CO}_{2}$ treatment.

In this review, we focus on the coupling of ultrasound technology with $\mathrm{sc} \mathrm{CO}_{2}$, for the inactivation (US SFI) of the most common food borne pathogens (Table 3) described above.

Ultrasound provokes acoustic cavitation with the periodic formation of micro bubbles followed by their violent collapse that are responsible for damages caused to cell walls and membranes of bacteria or yeasts leading to their inactivation.

The impact of $\mathrm{sc}^{\mathrm{CO}_{2}}$ assisted by ultrasound was evaluated to in activate microorganisms (E. coli and $S$. cerevisiae) in liquid and solid matrices [62]. In this work, it has been reported that using only sc $\mathrm{CO}_{2}$, without ultrasound assistance, leads to the complete inactivation $(78$ $\log$ cycles) of E. coli and S. cerevisiae after 25 and $140 \mathrm{~min}$ of $\mathrm{CO}_{2}$ $\left(35 \mathrm{MPa}, 36^{\circ} \mathrm{C}\right.$ ) treatment, respectively, which is considered relatively long and energy consuming. However, combining both processes of sc $\mathrm{CO}_{2}$ and ultrasound was efficient to reduce this time to $12 \mathrm{~min}$ for culture media and $\approx 4.9 \mathrm{~min}$ for juices (Fig. 4). On the other hand, for solid samples (chicken, turkey ham and dry cured pork cured ham), it has been reported that the inactivation rate of $E$. coli increased with temperature. Moreover, this rate was accelerated when using US SFI, and was more pronounced in treatments with isotonic solution sur rounding the solid food samples. The authors ascribed this result to the use of ultrasound that enhances the inactivation process by sc $\mathrm{CO}_{2}$. In fact, ultrasound process results in vigorous agitation that facilitated the solubilization of $\mathrm{CO}_{2}$ and enhanced the mass transfer process. In addi tion, the cavitation generated by ultrasound is able to cause substantial damage to the cell walls, which accelerates the extraction of vital constituents and leads to microbial death. The authors concluded that this combined process represents a great potential for reasonable al ternative method at industrial scale that could result in the reduction of

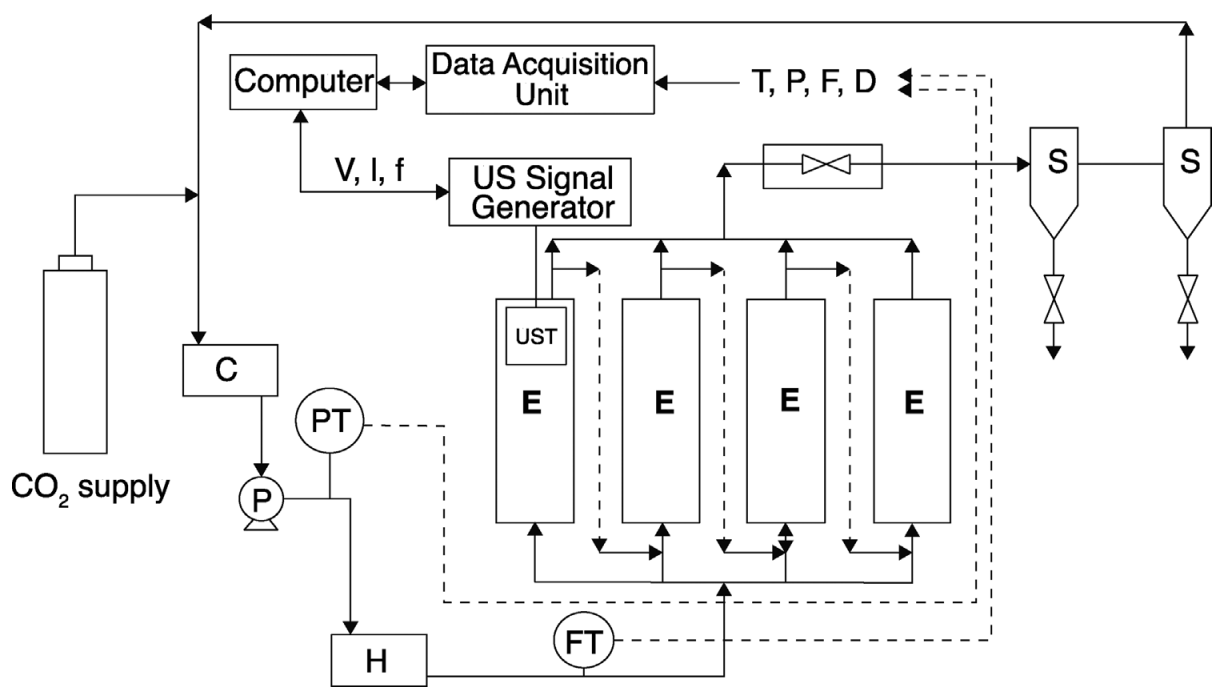

Fig. 3. Scheme of the SFE pilot plant assisted by power ultrasound. Units: (E) extractors, (S) separators, (C) cooler, (P) high pressure pump, $(\mathrm{H})$ heater, (PT) pressure meter, (FT) flow meter, (UST) ultrasonic transducer. Electrical parameters: (V) voltage, (I) current, (f) frequency. Extraction parameters: (T) temperature, (P) pressure, (F) $\mathrm{CO}_{2}$ flow rate, (D) density. Reprinted from [48] with permission. 
Table 2

Application of ultrasound-assisted supercritical fluid technology for the recovery of bioactive compounds.

\begin{tabular}{|c|c|c|c|}
\hline Description of the study & Process conditions & Major findings & References \\
\hline $\begin{array}{l}\text { Extraction of curcumin from turmeric } \\
\quad \text { (Curcuma longa L.) }\end{array}$ & $\begin{array}{l}\text { Temperature of } 50^{\circ} \mathrm{C} \text {, pressure of } 25 \mathrm{MPa} \text {, extraction time of } \\
90 \mathrm{~min}, \mathrm{CO}_{2} \text { flow rate of } 3 \mathrm{~mL} / \mathrm{min} \text { with } 10 \% \text { cosolvent }\end{array}$ & $\begin{array}{l}\text { Higher curcumin content in extraction yield and } \\
\text { shorter extraction time }\end{array}$ & [76] \\
\hline $\begin{array}{l}\text { Extraction of pungent compounds from a } \\
\text { typical herb (ginger) }\end{array}$ & $\begin{array}{l}\text { Pressure of } 160 \mathrm{bar} \text {, temperature of } 40^{\circ} \mathrm{C} \text {, US power of } 500 \mathrm{~W} \\
(20 \mathrm{kHz})\end{array}$ & $\begin{array}{l}\text { Extraction rate and yield were increased with US } \\
\text { assistance. }\end{array}$ & [21] \\
\hline $\begin{array}{l}\text { Lutein extraction from marigold (Tagetes } \\
\quad \text { erecta L.) }\end{array}$ & $\begin{array}{l}\text { Particle size of } 0.245-0.350 \mathrm{~mm} \text {, pressure of } 32.5 \mathrm{MPa} \text {, } \\
\text { temperature of } 55^{\circ} \mathrm{C}, \mathrm{CO}_{2} \text { flow rate of } 10 \mathrm{~kg} / \mathrm{h} \text {, ultrasonic } \\
\text { power of } 400 \mathrm{~W} \text {, ultrasonic frequency of } 25 \mathrm{kHz} \text { and ultrasonic } \\
\text { irradiation time/interval of } 6 / 9 \mathrm{~s} \text {. }\end{array}$ & The obtained yield of lutein esters was $690 \mathrm{mg} / 100 \mathrm{~g}$. & [50] \\
\hline $\begin{array}{l}\text { Extraction and removal of caffeine from } \\
\text { green tea. }\end{array}$ & $\begin{array}{l}\text { Pressure of } 30 \mathrm{MPa} \text {, temperature of } 55^{\circ} \mathrm{C} \text {, extraction duration } \\
\text { of } 4 \mathrm{~h} \text {, moisture content of } 30 \% \text {, and ultrasound power of } \\
100 \mathrm{~W}\end{array}$ & $\begin{array}{l}\text { The removal of caffeine from green tea without } \\
\text { damaging the structure of the active ingredients. }\end{array}$ & [51] \\
\hline $\begin{array}{l}\text { Extraction of oleanolic acid and ursolic } \\
\text { acid from Scutellaria barbata D. Don. }\end{array}$ & $\begin{array}{l}\text { Particle size of } 0.355 \mathrm{~mm} \text {, pressure of } 27.6 \mathrm{MPa} \text {, temperature } \\
\text { of } 55^{\circ} \mathrm{C}, \mathrm{CO}_{2} \text { flow rate of } 2.1 \mathrm{~mL} / \mathrm{min} \text {, extraction duration of } \\
50 \mathrm{~min} \text { and } 14.1 \% \text { (v/v) aqueous ethanol (ethanol/ } \\
\text { water }=80 / 20, \mathrm{v} / \mathrm{v} \text { ) as modifier. }\end{array}$ & $\begin{array}{l}\text { Similar extraction yield as for heat reflux extraction } \\
\text { (HRE). However, the extraction time was reduced } \\
\text { from } 180 \mathrm{~min} \text { to } 50 \mathrm{~min} \text {, for HRE and US-SFE, } \\
\text { respectively. }\end{array}$ & [52] \\
\hline $\begin{array}{l}\text { Extraction of triterpenic acids (oleanolic } \\
\text { and ursolic acids) from Hedyotis } \\
\text { diffusa and Hedyotis corymbosa. }\end{array}$ & $\begin{array}{l}\text { Extraction pressure at } 10.4-28.0 \mathrm{MPa} \text {, extraction temperature } \\
\text { at } 30-70^{\circ} \mathrm{C} \text {, extraction time of } 10-140 \mathrm{~min} \text {, mean particle size } \\
\text { at } 0.096-0.925 \mathrm{~mm} \text { and } \mathrm{CO}_{2} \text { flow rate at } 0.9-2.3 \mathrm{~mL} / \mathrm{min} \text {. US } \\
\text { power of } 185 \mathrm{~W}(40 \mathrm{kHz}) \text { and duty cycle of } 79 \% \text {. }\end{array}$ & $\begin{array}{l}\text { Better extraction yields, reducing the extraction time, } \\
\text { the solvent consumption and allowing milder } \\
\text { operating conditions. }\end{array}$ & [36] \\
\hline $\begin{array}{l}\text { Extraction of antioxidant compounds from } \\
\text { blackberry (Rubus sp.) bagasse } \\
\text { (industrial by-product). }\end{array}$ & $\begin{array}{l}\text { Temperature }\left(40,50 \text { and } 60^{\circ} \mathrm{C}\right) \text {, pressure }(15,20 \text { and } 25 \mathrm{MPa}) \text {, } \\
\text { and ultrasound power }(0,200 \text { and } 400 \mathrm{~W}) .\end{array}$ & $\begin{array}{l}\text { Extraction rate increased at the beginning of the } \\
\text { process. Higher antioxidant activity and phenolic } \\
\text { contents were obtained with higher temperatures. }\end{array}$ & [53] \\
\hline $\begin{array}{l}\text { Extraction of capsaicinoids from } \\
\text { malagueta pepper (Capsicum frutescens } \\
\text { L.). }\end{array}$ & $\begin{array}{l}\text { Pressure of } 15 \mathrm{MPa} \text {, temperature of } 40^{\circ} \mathrm{C} \text {, US power of } 360 \mathrm{~W} \\
\text { and extraction duration of } 60 \mathrm{~min}\end{array}$ & Increasing the extraction yield from $58 \%$ to $77 \%$. & [54] \\
\hline
\end{tabular}

Table 3

Application of ultrasound-assisted supercritical fluid technology for the inactivation of microorganisms.

\begin{tabular}{|c|c|c|c|}
\hline Description of the study & Process conditions & Major findings & References \\
\hline $\begin{array}{l}\text { Inactivation of } E \text {. coli and } S . \text { cerevisiae in } \\
\quad \text { liquid and solid matrices. }\end{array}$ & Pressure of $35 \mathrm{MPa}$ and temperature of $36^{\circ} \mathrm{C}$ & $\begin{array}{l}\text { Combining both processes of sc- }-\mathrm{CO}_{2} \text { and ultrasound was } \\
\text { efficient to reduce the inactivation time from up to } 140 \mathrm{~min} \\
\text { to } 1-2 \mathrm{~min} \text { for culture media and } \approx 4.9 \mathrm{~min} \text { for juices }\end{array}$ & [62] \\
\hline $\begin{array}{l}\text { Inactivation of } E \text {. coli in nutrient broth, } \\
\text { apple and orange juices. }\end{array}$ & $\begin{array}{l}\text { Pressures of } 10,22.5,29 \text { and } 35 \mathrm{MPa} ; 36^{\circ} \mathrm{C} \text {, and } \\
\text { temperatures of } 31^{\circ} \mathrm{C}, 36^{\circ} \mathrm{C} \text { and } 41^{\circ} \mathrm{C} ; 22.5 \mathrm{MPa} \text {. }\end{array}$ & $\begin{array}{l}\text { When combining ultrasound with } \mathrm{sc}-\mathrm{CO}_{2} \text {, the time needed to } \\
\text { reach the same inactivation level (than } \mathrm{sc}-\mathrm{CO}_{2} \text { alone) was } \\
\text { reduced by } 95 \% \text {. }\end{array}$ & [63] \\
\hline $\begin{array}{l}\text { Inactivation of } E \text {. coli, } S \text {. cerevisiae and } \\
\text { pectin methylesterase (PME) in } \\
\text { orange juice. }\end{array}$ & $\begin{array}{l}\text { Temperature of } 31-41^{\circ} \mathrm{C} ; 22.5 \mathrm{MPa} \text { and pressure of } \\
10-35 \mathrm{MPa} ; 36^{\circ} \mathrm{C} .\end{array}$ & $\begin{array}{l}\text { The inactivation rate of } E \text {. coli, S. cerevisiae and PME } \\
\text { increased proportionally to pressure and temperature during } \\
\text { treatments. }\end{array}$ & [64] \\
\hline $\begin{array}{l}\text { Inactivation of } E \text {. coli and } S . \text { cerevisiae in } \\
\text { apple juice. }\end{array}$ & $\begin{array}{l}\text { Pressures of } 10-35 \mathrm{MPa} \text { at } 36^{\circ} \mathrm{C} \text { and temperatures of } \\
31-41^{\circ} \mathrm{C} \text { at } 22.5 \mathrm{MPa} \text {. }\end{array}$ & $\begin{array}{l}\text { Shorter treatment times were needed to reach a total } \\
\text { inactivation of } S . \text { cerevisiae }(2-6 \mathrm{~min}) \text { than that of } E \text {. coli } \\
\text { ( } 7 \mathrm{~min}) \text {. }\end{array}$ & {$[65]$} \\
\hline $\begin{array}{l}\text { Pasteurization of fresh-cut coconut } \\
\text { spiked with Salmonella enterica } \\
\text { Typhimurium. }\end{array}$ & $\begin{array}{l}\text { Pressure of } 12 \mathrm{MPa} \text { and US power of } 10 \mathrm{~W} \text {, delivered every } \\
2 \mathrm{~min} \text { of treatment, as a function of temperature (from } 24 \\
\text { to } 50^{\circ} \mathrm{C} \text { ) and treatment time (from } 5 \text { up to } 30 \mathrm{~min} \text { ). }\end{array}$ & $\begin{array}{l}\text { Microbial inactivation was more efficient using US-SFI, } \\
\text { compared to } \mathrm{CO}_{2} \text { applied alone. }\end{array}$ & {$[67]$} \\
\hline $\begin{array}{l}\text { Inactivation of } L . \text { monocytogenes in dry } \\
\text { cured ham. }\end{array}$ & $\begin{array}{l}\text { Pressures }(6,8 \text { and } 12 \mathrm{MPa}) \text { of } \mathrm{CO}_{2} \text {, temperatures }(22,35 \text {, } \\
\left.45^{\circ} \mathrm{C}\right) \text {, and treatment times }(0.5-30 \mathrm{~min}) .\end{array}$ & $\begin{array}{l}\text { The initial microbial load of } L \text {. monocytogenes }\left(10^{9} \mathrm{CFU} / \mathrm{g}\right) \\
\text { was reduced below the limit of detection. }\end{array}$ & [75] \\
\hline
\end{tabular}

cost, with minimal nutritional and organoleptic changes. The damages generated by US SFI treatment were strong enough to avoid a possible regrowth of cells during post treatment storage during 6 weeks at $4{ }^{\circ} \mathrm{C}$.

Similar study was conducted for the inactivation of $E$. coli in nu trient broth, apple and orange juices [63]. Different combinations of pressures and temperatures (see Table 3) were investigated. Results demonstrated that using $\mathrm{sc} \mathrm{CO}_{2}$ individually without ultrasound assis tance for microbial inactivation in LB broth was proportionally in creasing to the applied pressure or temperature. The average time needed to achieve a reduction of $8 \log$ cycles was $50 \mathrm{~min}$. However, when combining ultrasound with sc $\mathrm{CO}_{2}$, the time needed to reach the same inactivation level was reduced by $95 \%$, with non significant effect of pressure and temperature; this reduction being achieved after only 2 min at $31{ }^{\circ} \mathrm{C}$ and $22.5 \mathrm{MPa}$. The authors concluded that US SFI al lowed reducing the treatment time, regardless of the treatment medium, which prevents the inhibitory effect on the sc $\mathrm{CO}_{2}$ inactiva tion, generated by the juice solutes.

The same research group investigated the feasibility of using US SFI for the inactivation of $E$. coli, S. cerevisiae and pectin methylesterase
(PME) in orange juice [64]. The idea was to propose a model that can predict the inactivation behaviour based on the process conditions. Different parameters were studied including temperature and pressure. Results showed that the inactivation rate of E. coli, S. cerevisiae and PME increased proportionally to pressure and temperature during treat ments. The biphasic, Peleg type B, and the fractional models were re spectively used to propose models for temperature, pressure and treatment time as variables. The authors concluded that the batch system of the combined US SFI process allows the use of mild process conditions and shorter treatment times than those of continuous sc $\mathrm{CO}_{2}$ systems.

Similar work was performed for the inactivation of $E$. coli and $S$. cerevisiae in apple juice [65]. In this work, different pressures and temperatures were studied (Table 3). Results demonstrated that in general, shorter treatment times were needed to reach a total in activation of $S$. cerevisiae $(26 \mathrm{~min})$ than that of $E$. coli $(7 \mathrm{~min})$. It has been also reported that, when considering temperature and pressure as model parameters, the inactivation kinetics of E. coli and S. cerevisiae were satisfactorily described by the Peleg type A and the Weibull 

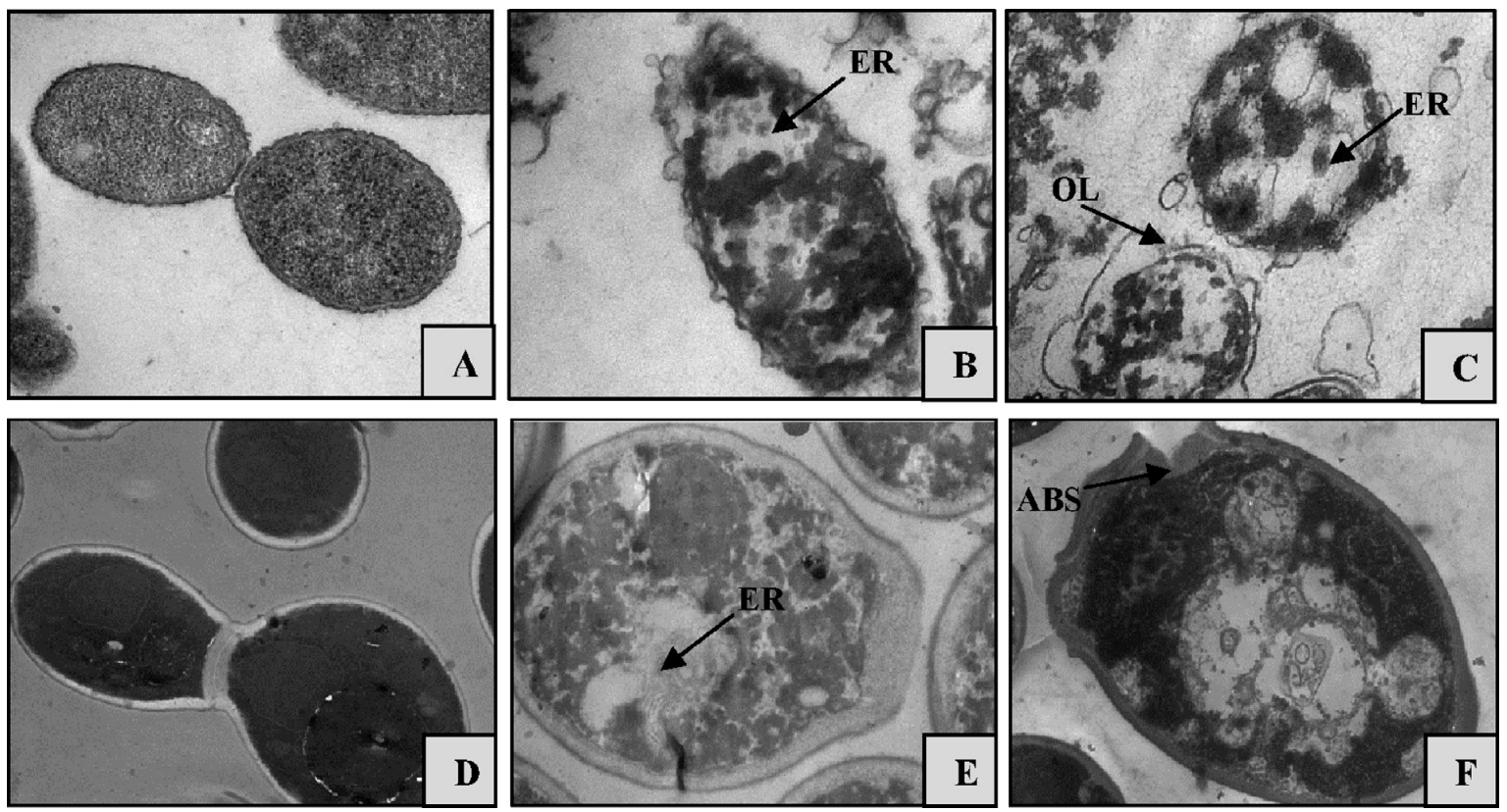

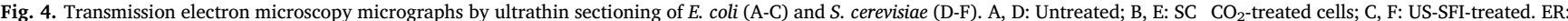
empty regions; OL: cell wall-outer layer; ABS: abnormal bud scars. Reprinted from [62] with permission.

model, respectively. Microscopic images revealed that after 5 min of sc $\mathrm{CO}_{2}$ treatment alone $\left(35 \mathrm{MPa}, 36^{\circ} \mathrm{C}\right)$, minor morphological modifica tions were observed on cells, without any inactivation. However, when treating the cells under the same conditions with assistance of ultra sound $(40 \mathrm{~W})$, total inactivation was observed for both microorganisms. The treatment revealed the degradation of the internal cell content and the disruption of the cell plasmalemma, which is effective to prevent the regrowth of the cells during chilled storage.

Salmonella is the second most common cause of food poisoning after Campylobacter. The cause of salmonellosis is mainly attributed to the ingestion of Salmonella spp. After consuming contaminated foods, the symptoms (diarrhea, abdominal cramps, nausea, vomiting, fever, headache, and blood in the feces [66]) usually appear after $1272 \mathrm{~h}$ and last for 47 days. Its inactivation is required to ensure microbiologically safe food products. As emerging technology, US SFI was evaluated for the pasteurization of fresh cut coconut [67]. Samples were first spiked with Salmonella enterica Typhimurium, and then processed for in activation. The optimal conditions for inactivating both natural mi crobiota and the spiked ones were found at $12 \mathrm{MPa}$ and $10 \mathrm{~W}$, delivered every $2 \mathrm{~min}$ of treatment, as a function of temperature (from 24 to $50{ }^{\circ} \mathrm{C}$ ) and treatment time (from 5 up to $30 \mathrm{~min}$ ). Physicochemical analyses (total acidity, $\mathrm{pH}$, color, texture, dry matter, fat content, en zymatic activity, antioxidant capacity, phenols, flavonoids, and phe nolic acids) were performed to study the impact of the process on the product quality following the treatment and during chilled storage of 4 weeks. The authors reported that microbial inactivation was more ef ficient using US SFI, compared to $\mathrm{CO}_{2}$ applied alone. In fact, 8 log re duction of $S$. Typhimurium was achieved when using US SFI at $12 \mathrm{MPa}$, $40^{\circ} \mathrm{C}$, and $20 \mathrm{~min}$, whereas only $4 \log$ reduction was achieved using $\mathrm{CO}_{2}$ sole. Similar results were observed for natural microbiota, reducing their counts below the limit of detection, even for mesophilic micro organisms, which are very resistant. It has been also reported that the treatment did not lead to any change in total acidity during the total storage of 4 weeks, while minor changes were observed for the other physicochemical parameters. The authors concluded that US SFI re presents a promising potential for the industrial pasteurization of fresh cut fruits.

Another major pathogen that is also drawing attention for its in activation is Listeria monocytogenes. This microorganism represents the ability to grow under aerobic and anaerobic conditions [68], at a wide range of temperature $\left(0.4^{\circ} \mathrm{C}\right.$ to $45^{\circ} \mathrm{C}$ ) [69,70], over a wide $\mathrm{pH}$ range from 4.0 to 9.6 [71], in a modified atmosphere packaging [72], and even at relatively low water activity levels [73]. These features make Listeria a serious concern in food industry that requires strong controls along the food chain [74].

For instance, dry cured ham spiked with $L$. monocytogenes were treated by US SFI and the impact of this combined technology in in activating the microorganism was evaluated [75]. Different pressures (6, 8 and $12 \mathrm{MPa})$ of $\mathrm{CO}_{2}$, temperatures $\left(22,35,45^{\circ} \mathrm{C}\right.$ ), and treatment times $(0.530 \mathrm{~min})$ were studied, and their impact on $L$. monocytogenes inactivation was compared to that of thermal and US SFI treatments. Following the inactivation process, different parameters including color, $\mathrm{pH}$, and acidity changes were evaluated. A sensory analysis was also performed for the treated samples, and the shelf life was de termined by a storage study for 4 weeks at $4{ }^{\circ} \mathrm{C}$. Results demonstrated that applying ultrasound alone was not sufficient for microbial in activation. However, applying US SFI achieved a certain level of in activation, depending on the process temperature used. The efficiency of inactivation was reaching a maximum at $35^{\circ} \mathrm{C}$ rather than $22^{\circ} \mathrm{C}$ and no further increase was observed at $45^{\circ} \mathrm{C}$ when compared to $35^{\circ} \mathrm{C}$. It has been also reported that when processing the samples at $12 \mathrm{MPa}$, $35^{\circ} \mathrm{C}$, at $10 \mathrm{~W}$ for $5 \mathrm{~min}$, the initial microbial load of L. monocytogenes $\left(10^{9} \mathrm{CFU} / \mathrm{g}\right)$ was reduced below the limit of detection. No significant changes in acidity, $\mathrm{pH}$, color, and sensory attributes were noticed be tween the treated and the untreated dry cured ham samples. In addition to these results, it has been also reported that a full microbial and quality shelf life was assured for 4 weeks at $4{ }^{\circ} \mathrm{C}$. The authors concluded that US SFI represents the potential to be used as alternative technology to inactivate microorganisms at industrial scale, in particular to treat ham type or meat products.

\section{Current challenges of US-SF treatments: knowledge gaps, limitations, future directions, and industrial perspectives}

Combined US SF (both US SFE and US SFI) green technology re presents a great potential for many purposes including vegetable oil extraction, recovery of high added value compounds, and inactivation of microorganisms. Most of the works cited in this review point out the 
efficiency of this method to be used at industrial scale, and the possi bility to upgrade the current sc $\mathrm{CO}_{2}$ installations used in food industry with ultrasound probes and high frequency generators.

\subsection{Extraction of valuable substances}

The combined method of US SFE demonstrated its ability to reduce the processing time, the temperature, and the use of organic solvents, without significantly affecting the sensory and textural properties of the final product. In addition to these benefits, the use of $\mathrm{sc}^{\mathrm{CO}_{2}}$ allows a fast and complete separation of the extract (oil and bioactives) by simply reducing the pressure and leaving no residue at all in the final product. Consequently, less purification steps for extract/solvent se paration are required, although this separation might be sometimes needed when using co solvents in addition to $\mathrm{sc}^{\mathrm{CO}_{2}}$. Another major advantage lies in the quality of the obtained product. In most - if not all cases, supercritical extract is considered as the highest possible quality product.

Despite of all of these benefits, the use of this new technology re quires more investigations before it becomes a common practice in the food industry. First of all, no global and precise energy balance of this emerging technique has been reported yet in the literature, which is one of the keys to scale up. It is known that using sc $\mathrm{CO}_{2}$ alone was faced to the high consumed volumes of $\mathrm{CO}_{2}$, requiring further energy for pumping, and thus could only be applied to products with high added value. This drawback might however be attenuated by the fact that $\mathrm{CO}_{2}$ is usually pumped in its liquid incompressible state which consumes rather little energy. In addition, $\mathrm{CO}_{2}$ can be recycled reducing drasti cally the quantities used. Another disadvantage that is often cited is the relatively high investment cost, which is linked to the use of high pressures. To determine the profitability of any new technology or process to be implemented at industrial scale, it is necessary to calculate the added value obtained by this new system, which is highly variable and in many cases very difficult to quantify as it is related to how much the consumer is willing to pay, and the economic cost associated with the use of this new technology. Moreover, most of the works available in the literature were performed in the laboratory scale using batch equipments. Some studies showed that the efficiency of ultrasound techniques drops dramatically for larger volumes. The origins of this efficiency drop are unknown and should be studied. Therefore, the development of equipment coupling US and SFE and operating con tinuously should be carefully investigated. This task will not be easy because many constraints (gas sealing, cavitation erosion, etc.) must be taken into account in the design. In addition, global life cycle assess ment of the product must be performed to determine the impact of technology on the environment of all the new stages of the product manufacture process. Equipping the current SFE installations with US probes may significantly increase the cost of the product without im proving its quality. Thus, a compromise should be taken into account between the total investment, the final value of the product, and the additional extraction yield generated by ultrasound. The industrial fu ture of this technology will probably lies in the design of continuous processing equipment, which is quite challenging. The sequential/ multistage use of US SFE with other conventional or non conventional technologies will open new perspectives to improve the efficiency and to shorten the extraction times of oils and bioactive compounds. The second point that should be taken into consideration is that the pro posed technique of US SFE for seed oil extraction should be compared to other non conventional technologies such as gas assisted mechanical expression, which was successfully applied to extract seed oils. The comparison should consider the total yield (for oils/bioactives), the consumed energy, the treatment time, and the amount of materials that could be processed per day. The required investment should also be considered for evaluation.

\subsection{Inactivation of microorganisms}

Inactivating microorganisms using US SFI for food preservation is an interesting non thermal technology. As compared to thermal tech nologies, it offers many advantages to the food processor, including the preservation of quality, minimization of loss of flavors and nutrients, fresh like taste, and energy savings. Moreover, US SFI should be com pared to other recent technologies (pulsed electric field, arc discharge processing, ultraviolet light, hydrostatic pressure processing, etc.). For instance, high hydrostatic pressure processing is currently more and more used in food industry as an alternative to heat sterilization and pasteurization. The use of irradiation is also an efficient method for food sterilization. Its social acceptability may however vary depending on the country and therefore impair its broad dissemination.

In addition to these economic features, more fundamental studies should be conducted to better understand the mechanisms of microbial inactivation during US SFI. For example, it is commonly accepted that gram negative bacteria (i.e. with a thin and mono layered cell wall) are more sensitive to inactivation than gram positive bacteria (thick and multi layered cell wall) but the link between the efficiency of US SFI and the type of cell wall has never been elucidated nor even studied. The presence - or absence of a capsule around the cell wall is another example of parameter to be studied. When ultrasound is used alone, the higher the intensity, the more inactivated the bacteria, since more en ergy is released at higher intensity. But the way the synergy with su percritical $\mathrm{CO}_{2}$ takes place is completely unknown. This is true not only with intensity but also with other parameters (US power, frequency, etc), which may have been studied for the ultrasonication of foods but not in association with compressed gases such as carbon dioxide.

To sum up the main challenges to overcome in this new coupled technology of inactivation of microorganisms are: (i) to get more stu dies with very precise description of experimental procedures in order to make possible some comparison (ii) to better understand and eluci date the phenomena of inactivation by acoustic cavitation, by pres surized carbon dioxide and above all by the two combined technolo gies. Moreover, the combination of high $\mathrm{CO}_{2}$ pressure ( $>30 \mathrm{MPa}$ ) and high US power ( $>300 \mathrm{~W}$ ) should be tested, as no study has been de voted to it yet. In addition, few studies have focused on the impact of this technology on the organoleptic properties of the processed foods and this point should be explored in depth. Finally, there is a lack in the literature for works performed at either pilot or industrial scale to justify if this process is economically viable and if the achievements at laboratory could be scaled up.

\section{References}

[1] J. Azmir, I.S.M. Zaidul, M.M. Rahman, K.M. Sharif, A. Mohamed, F. Sahena, M.H.A. Jahurul, K. Ghafoor, N.A.N. Norulaini, A.K.M. Omar, Techniques for extraction of bioactive compounds from plant materials: a review, J. Food Eng. 117 (2013) 426-436.

[2] S. Sasidharan, Y. Chen, D. Saravanan, K.M. Sundram, L. Yoga Latha, Extraction, isolation and characterization of bioactive compounds from plants' extracts, Afr. J. Tradit. Complement. Altern. Med. 8 (2010) 1-10.

[3] M. Déniel, G. Haarlemmer, A. Roubaud, E. Weiss-Hortala, J. Fages, Energy valorisation of food processing residues and model compounds by hydrothermal liquefaction, Renew. Sustain. Energy Rev. 54 (2016) 1632-1652.

[4] F. Chemat, M.A. Vian, G. Cravotto, Green extraction of natural products: concept and principles, Int. J. Mol. Sci. 13 (2012) 8615-8627.

[5] L. Wang, C.L. Weller, Recent advances in extraction of nutraceuticals from plants, Trends Food Sci. Technol. 17 (2006) 300-312.

[6] M. Koubaa, F.J. Barba, H. Mhemdi, N. Grimi, W. Koubaa, E. Vorobiev, Gas Assisted Mechanical Expression (GAME) as a promising technology for oil and phenolic compound recovery from tiger nuts, Innov. Food Sci. Emerg. Technol. 32 (2015) 172-180.

[7] E. Roselló-Soto, O. Parniakov, Q. Deng, A. Patras, M. Koubaa, N. Grimi, N. Boussetta, B.K. Tiwari, E. Vorobiev, N. Lebovka, F.J. Barba, Application of nonconventional extraction methods: toward a sustainable and green production of valuable compounds from mushrooms, Food Eng. Rev. 8 (2015) 214-234.

[8] S. Bover-Cid, N. Belletti, M. Garriga, T. Aymerich, Response surface methodology to investigate the effect of high pressure processing on Salmonella inactivation on drycured ham, Food Res. Int. 45 (2012) 1111-1117. 
[9] M. de Alba, D. Bravo, M. Medina, High pressure treatments on the inactivation of Salmonella Enteritidis and the characteristics of beef carpaccio, Meat Sci. 92 (2012) 823-828.

[10] F.V.M. Silva Evelyn, High pressure processing of milk: modeling the inactivation of

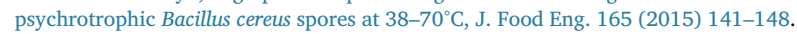

[11] K. Aronsson, M. Lindgren, B.R. Johansson, U. Rönner, Inactivation of microorganisms using pulsed electric fields: the influence of process parameters on Escherichia coli, Listeria innocua, Leuconostoc mesenteroides and Saccharomyces cerevisiae, Innov. Food Sci. Emerg. Technol. 2 (2001) 41-54.

[12] T. Grahl, H. Märkl, Killing of microorganisms by pulsed electric fields, Appl. Microbiol. Biotechnol. 45 (1996) 148-157.

[13] P.C. Wouters, J.P.P.M. Smelt, Inactivation of microorganisms with pulsed electric fields: potential for food preservation, Food Biotechnol. 11 (1997) 193-229.

[14] P. Piyasena, E. Mohareb, R.C. McKellar, Inactivation of microbes using ultrasound: a review, Int. J. Food Microbiol. 87 (2003) 207-216.

[15] A.K. Dillow, F. Dehghani, J.S. Hrkach, N.R. Foster, R. Langer, Bacterial inactivation by using near- and supercritical carbon dioxide, Proc. Natl. Acad. Sci. 96 (1999) 10344-10348.

[16] M. Perrut, Sterilization and virus inactivation by supercritical fluids (a review), J. Supercrit. Fluids 66 (2012) 359-371.

[17] J. Fages, B. Poirier, Y. Barbier, P. Frayssinet, M.L. Joffret, W. Majewski, G. Bonel, D. Larzul, Viral inactivation of human bone tissue using supercritical fluid extraction, Am. Soc. Artif. Intern. Organs. 44 (1998) 289-293.

[18] P. Willems, N.J.M. Kuipers, A.B. de Haan, Gas assisted mechanical expression of oilseeds: influence of process parameters on oil yield, J. Supercrit. Fluids 45 (2008) 298-305.

[19] M. Koubaa, L. Lepreux, F.J. Barba, H. Mhemdi, E. Vorobiev, Gas assisted mechanical expression (GAME) for the selective recovery of lipophilic and hydrophilic compounds from olive kernel, J. Clean. Prod. 166 (2017) 387-394.

[20] M. Müller, R. Eggers, Gas-assisted oilseed pressing on an industrial scale, J. Am. Oil Chem. Soc. 91 (2014) 1633-1641.

[21] S. Balachandran, S.E. Kentish, R. Mawson, M. Ashokkumar, Ultrasonic enhancement of the supercritical extraction from ginger, Ultrason. Sonochem. 13 (2006) $471-479$.

[22] J.-L. Capelo-Martínez, Ultrasound in Chemistry: Analytical Applications, WileyVCH, Weinheim, 2009

[23] T.J. Mason, Sonochemistry, Oxford University Press, Oxford; New York, 1999.

[24] N. Pokhrel, P.K. Vabbina, N. Pala, Sonochemistry: science and engineering, Ultrason. Sonochem. 29 (2016) 104-128.

[25] M.Y. Heng, S.N. Tan, J.W.H. Yong, E.S. Ong, Emerging green technologies for the chemical standardization of botanicals and herbal preparations, TrAC Trends Anal. Chem. 50 (2013) 1-10.

[26] F.J. Barba, N. Grimi, E. Vorobiev, New approaches for the use of non-conventional cell disruption technologies to extract potential food additives and nutraceuticals from microalgae, Food Eng. Rev. 7 (2014) 45-62.

[27] A. Khoddami, M.A. Wilkes, T.H. Roberts, Techniques for analysis of plant phenolic compounds, Molecules 18 (2013) 2328-2375.

[28] M. Virot, V. Tomao, C. Le Bourvellec, C.M.C.G. Renard, F. Chemat, Towards the industrial production of antioxidants from food processing by-products with ultrasound-assisted extraction, Ultrason. Sonochem. 17 (2010) 1066-1074.

[29] D. Pingret, A.-S. Fabiano-Tixier, C.L. Bourvellec, C.M.G.C. Renard, F. Chemat, Lab and pilot-scale ultrasound-assisted water extraction of polyphenols from apple pomace, J. Food Eng. 111 (2012) 73-81.

[30] S. Khodadoust, H. Sadeghi, A.A. Pebdani, J. Mohammadi, A. Salehi, Optimization of ultrasound-assisted extraction of colchicine compound from Colchicum haussknechtii by using response surface methodology, J. Saudi Soc. Agric. Sci. 16 (2015) $163-170$.

[31] L. Orio, L. Alexandru, G. Cravotto, S. Mantegna, A. Barge, UAE, MAE, SFE- $\mathrm{CO}_{2}$ and classical methods for the extraction of Mitragyna speciosa leaves, Ultrason. Sonochem. 19 (2012) 591-595.

[32] O. Parniakov, E. Apicella, M. Koubaa, F.J. Barba, N. Grimi, N. Lebovka, G. Pataro, G. Ferrari, E. Vorobiev, Ultrasound-assisted green solvent extraction of high-added value compounds from microalgae Nannochloropsis spp, Bioresour. Technol. 198 (2015) 262-267.

[33] F.S. Taha, G.F. Mohamed, S.H. Mohamed, S.S. Mohamed, M.M. Kamil, Optimization of the extraction of total phenolic compounds from sunflower meal and evaluation of the bioactivities of chosen extracts, Am. J. Food Technol. 6 (2011) 1002-1020.

[34] A. Hu, S. Zhao, H. Liang, T. Qiu, G. Chen, Ultrasound assisted supercritical fluid extraction of oil and coixenolide from adlay seed, Ultrason. Sonochem. 14 (2007) 219-224.

[35] E. Riera, Y. Golás, A. Blanco, J.A. Gallego, M. Blasco, A. Mulet, Mass transfer enhancement in supercritical fluids extraction by means of power ultrasound, Ultrason. Sonochem. 11 (2004) 241-244.

[36] M.-C. Wei, Y.-C. Yang, Kinetic studies for ultrasound-assisted supercritical carbon dioxide extraction of triterpenic acids from healthy tea ingredient Hedyotis diffusa and Hedyotis corymbosa, Sep. Purif. Technol. 142 (2015) 316-325.

[37] V.J. Krukonis, M.A. MacHugh, Supercritical Fluid Extraction: Principles and Practice, Butterworth-Heinemann, Boston, 1994.

[38] M. Herrero, A. Cifuentes, E. Ibañez, Sub- and supercritical fluid extraction of functional ingredients from different natural sources: plants, food-by-products, algae and microalgae: a review, Food Chem. 98 (2006) 136-148.

[39] N. Rombaut, A.-S. Tixier, A. Bily, F. Chemat, Green extraction processes of natural products as tools for biorefinery, Biofuels Bioprod. Biorefining. 8 (2014) 530-544.

[40] J.M. Andersson, S. Lindahl, C. Turner, I. Rodriguez-Meizoso, Pressurised hot water extraction with on-line particle formation by supercritical fluid technology, Food Chem. 134 (2012) 1724-1731.
[41] G. Brunner, Near critical and supercritical water Part I. Hydrolytic and hydrothermal processes, J. Supercrit. Fluids. 47 (2009) 373-381.

[42] M. Déniel, G. Haarlemmer, A. Roubaud, E. Weiss-Hortala, J. Fages, Optimisation of bio-oil production by hydrothermal liquefaction of agro-industrial residues: blackcurrant pomace (Ribes nigrum L.) as an example, Biomass Bioenergy. 95 (2016) 273-285.

[43] P.J. Walkelyn, P.J. Wan, Solvent extraction to obtain edible oil products, in: C.C. Akoh (Ed.), Handb. Funct. Lipids, CRC Press, Boca Raton, 2006, pp. 89-131.

[44] U.G. Akpan, Oilseeds, InTech, Rijeka, Croatia, 2012.

[45] C.B. Rempel, M.G. Scanlon, The potential for ultrasound and supercritical fluid extraction for value-added processing of canola, in: U. Thiyam-Hollaender, N.A.M. Eskin, B. Matthäus (Eds.), Canola Rapeseed, CRC Press, Boca Raton, 2012, pp. $145-170$.

[46] P. dos Santos, A.C. de aguiar, J. viganó, J.S. boeing, J.V., visentainer, J. martínez supercritical $\mathrm{CO}_{2}$ extraction of cumbaru oil (Dipteryx alata vogel) assisted by ultrasound: global yield, kinetics and fatty acid composition, J. Supercrit. Fluids. 107 (2016) 75-83.

[47] F.M. Barrales, C.A. Rezende, J. Martínez, Supercritical $\mathrm{CO}_{2}$ extraction of passion fruit (Passiflora edulis sp.) seed oil assisted by ultrasound, J. Supercrit. Fluids. 104 (2015) 183-192.

[48] E. Riera, A. Blanco, J. García, J. Benedito, A. Mulet, J.A. Gallego-Juárez, M. Blasco, High-power ultrasonic system for the enhancement of mass transfer in supercritical $\mathrm{CO}_{2}$ extraction processes, Phys. Proc. 3 (2010) 141-146.

[49] J. Luo, Z. Fang, R.L. Smith, Ultrasound-enhanced conversion of biomass to biofuels, Prog. Energy Combust. Sci. 41 (2014) 56-93.

[50] Y. Gao, B. Nagy, X. Liu, B. Simándi, Q. Wang, Supercritical $\mathrm{CO}_{2}$ extraction of lutein esters from marigold (Tagetes erecta L.) enhanced by ultrasound, J. Supercrit. Fluids. 49 (2009) 345-350.

[51] W.-Q. Tang, D.-C. Li, Y.-X. Lv, J.-G. Jiang, Extraction and removal of caffeine from green tea by ultrasonic-enhanced supercritical fluid, J. Food Sci. 75 (2010) C363-368.

[52] Y.-C. Yang, M.-C. Wei, S.-J. Hong, T.-C. Huang, S.-Z. Lee, Development/optimization of a green procedure with ultrasound-assisted improved supercritical carbon dioxide to produce extracts enriched in oleanolic acid and ursolic acid from Scutellaria barbata D. Don, Ind. Crops Prod. 49 (2013) 542-553.

[53] J.L. Pasquel Reátegui, A.P.F. da Machado, G.F. Barbero, C.A. Rezende, J. Martínez Extraction of antioxidant compounds from blackberry (Rubus sp.) bagasse using supercritical $\mathrm{CO}_{2}$ assisted by ultrasound, J. Supercrit. Fluids 94 (2014) 223-233.

[54] P. Santos, A.C. Aguiar, G.F. Barbero, C.A. Rezende, J. Martínez, Supercritical carbon dioxide extraction of capsaicinoids from malagueta pepper (Capsicum frutescens L.) assisted by ultrasound, Ultrason. Sonochem. 22 (2015) 78-88.

[55] V. Velusamy, K. Arshak, O. Korostynska, K. Oliwa, C. Adley, An overview of foodborne pathogen detection: in the perspective of biosensors, Biotechnol. Adv. 28 (2010) 232-254.

[56] E.C. Alocilja, S.M. Radke, Market analysis of biosensors for food safety, Biosens. Bioelectron. 18 (2003) 841-846.

[57] S. Chemburu, E. Wilkins, I. Abdel-Hamid, Detection of pathogenic bacteria in food samples using highly-dispersed carbon particles, Biosens. Bioelectron. 21 (2005) 491-499.

[58] F.J. Barba, M. Koubaa, L. do Prado-Silva, V. Orlien, A. de Souza Sant'Ana, Mild processing applied to the inactivation of the main foodborne bacterial pathogens: a review, Trends Food Sci. Technol. 66 (2017) 20-35.

[59] S. Spilimbergo, N. Elvassore, A. Bertucco, Microbial inactivation by high-pressure, J. Supercrit. Fluids. 22 (2002) 55-63.

[60] L. Garcia-Gonzalez, A.H. Geeraerd, S. Spilimbergo, K. Elst, L. Van Ginneken, J. Debevere, J.F. Van Impe, F. Devlieghere, High pressure carbon dioxide in activation of microorganisms in foods: the past, the present and the future, Int. J. Food Microbiol. 117 (2007) 1-28.

[61] S. Spilimbergo, D. Mantoan, A. Quaranta, G.D. Mea, Real-time monitoring of cell membrane modification during supercritical $\mathrm{CO}_{2}$ pasteurization, J. Supercrit. Fluids. 48 (2009) 93-97.

[62] J. Benedito, C. Ortuño, R.I. Castillo-Zamudio, A. Mulet, Microbial inactivation by ultrasound assisted supercritical fluids, Phys. Procedia. 70 (2015) 824-827.

[63] C. Ortuño, M.T. Martínez-Pastor, A. Mulet, J. Benedito, An ultrasound-enhanced system for microbial inactivation using supercritical carbon dioxide, Innov. Food Sci. Emerg. Technol. 15 (2012) 31-37.

[64] C. Ortuño, M. Balaban, J. Benedito, Modelling of the inactivation kinetics of Escherichia coli, Saccharomyces cerevisiae and pectin methylesterase in orange juice treated with ultrasonic-assisted supercritical carbon dioxide, J. Supercrit. Fluids. 90 (2014) 18-26.

[65] C. Ortuño, A. Quiles, J. Benedito, Inactivation kinetics and cell morphology of E. coli and $S$. cerevisiae treated with ultrasound-assisted supercritical $\mathrm{CO}_{2}$, Food Res. Int. 62 (2014) 955-964.

[66] C. Poppe, Pathogens in milk | salmonella spp, in: J.W. Fuquay (Ed.), Encycl. Dairy Sci. second ed., Academic Press, San Diego, 2011, pp. 93-98.

[67] G. Ferrentino, D. Komes, S. Spilimbergo, High-power ultrasound assisted highpressure carbon dioxide pasteurization of fresh-cut coconut: a microbial and physicochemical study, Food Bioprocess Technol. 8 (2015) 2368-2382

[68] A.-L. Välimaa, A. Tilsala-Timisjärvi, E. Virtanen, Rapid detection and identification methods for Listeria monocytogenes in the food chain A review, Food Control. 55 (2015) 103-114.

[69] J.R. Junttila, S.I. Niemelä, J. Hirn, Minimum growth temperatures of Listeria monocytogenes and non-haemolytic Listeria, J. Appl. Bacteriol. 65 (1988) 321-327.

[70] S.J. Walker, P. Archer, J.G. Banks, Growth of Listeria monocytogenes at refrigeration temperatures, J. Appl. Bacteriol. 68 (1990) 157-162.

[71] J.M. Farber, P.I. Peterkin, Listeria monocytogenes, a food-borne pathogen, Microbiol. 
Rev. 55 (1991) 476-511.

[72] B. Swaminathan, P. Gerner-Smidt, The epidemiology of human listeriosis, Microbes Infect. Inst. Pasteur. 9 (2007) 1236-1243.

[73] J.M. Farber, F. Coates, E. Daley, Minimum water activity requirements for the growth of Listeria monocytogenes, Lett. Appl. Microbiol. 15 (1992) 103-105.

[74] S.T. Lambertz, S. Ivarsson, G. Lopez-Valladares, M. Sidstedt, R. Lindqvist, Subtyping of Listeria monocytogenes isolates recovered from retail ready-to-eat foods, processing plants and listeriosis patients in Sweden 2010, Int. J. Food Microbiol. 166
(2013) 186-192.

[75] S. Sara, C. Martina, F. Giovanna, High pressure carbon dioxide combined with high power ultrasound processing of dry cured ham spiked with Listeria monocytogenes, Food Res. Int. 66 (2014) 264-273.

[76] K. Chhouk, H. Wahyudiono, M. Kanda Goto, Comparison of conventional and ultrasound assisted supercritical carbon dioxide extraction of curcumin from turmeric (Curcuma longa L.), Eng. J. 21 (2017) 53-65. 